TẠP CHÍ KHOA HỌC ĐẠI HỌC TÂN TRÀO
ISSS: 2354 - 1431
http://tckh.daihoctantrao.edu.vn/

\title{
MộT SỐ KÊTT QUẢ THỰC HIỆN CHÍNH SÁCH DÂN TộC Ở TỈNH TUYÊN QUANG
}

\author{
Lê Thị Hồng Hạnh ${ }^{1^{*}}$, Trần Thị Phương ${ }^{1}$ \\ ${ }^{1}$ Trường Chính trị tỉnh Tuyên Quang \\ *Email: honghanhtq1987@gmail.com
}

\section{Thông tin bài viết}

Ngày nhận bài:

28/4/2020

Ngày duyệt đăng:

20/9/2020

Từ khóa:

dân tộc, chính sách dân

tộc, tỉnh Tuyên Quang, dân

tộc thiểu số, vùng dân tộc

thiểu số.

\section{Tóm tắt}

Chính sách dân tộc là một trong những nội dung quan trọng nhằm phát triển kinh tế - xã hội vùng dân tộc thiểu số ở nước ta. Bài viết này tập trung đánh giá những kết quả đã đạt được cũng như những tồn tại, hạn chế trong quá trình thực hiện chính sách dân tộc ở tỉnh Tuyên Quang, từ đó đề ra giải pháp để nâng cao hiệu quả thực hiện chính sách dân tộc trên địa bàn tỉnh Tuyên Quang hiện nay.

\section{1. Đặt vấn đề}

Việt Nam là quốc gia thống nhất gồm 54 dân tộc sinh sống, trong đó có 53 dân tộc thiểu số. Hầu hết các dân tộc thiểu số cư trú trên địa bàn có vị trí chiến lược đặc biệt quan trọng về chính trị, kinh tế, quốc phòng, an ninh và môi trường sinh thái. Trong tiến trình hàng nghìn năm dựng nước và giữ nước của dân tộc ta, cộng đồng các dân tộc Việt Nam có vai trò đặc biệt quan trọng, tạo nên sức mạnh to lớn trong sự nghiệp xây dựng và bảo vệ Tổ quốc. Nhận thức rõ điều đó, trong quá trình lãnh đạo đất nước, Đảng và Nhà nước ta đã đề ra nhiều chủ trương, chính sách phù hợp với thực tiễn đất nước, đảm bảo nguyên tắc "bình đẳng, đoàn kết, tôn trọng và giúp nhau cùng phát triển" $[1 ; 70]$.

Tuyên Quang là một tỉnh miền núi nằm ở phía Bắc Việt Nam. Diện tích đất tự nhiên $5.868 \mathrm{~km}^{2}$. Tỉnh có 07 đơn vị hành chính cấp huyện, trong đó có 02 huyện nghèo (huyện Na Hang và huyện Lâm Bình). Dân số toàn tỉnh hơn 784.000 người với 22 dân tộc cùng chung sống, trong đó dân tộc thiểu số 445.504 người, chiếm 56,7\%, gồm: dân tộc Tày chiếm 25,5\%, Dao chiếm 12,7\%, Sán Chay chiếm $8,7 \%$, Mông 2,3\%, Nùng chiếm 1,9\%, Sán Dìu chiếm $1,7 \%$, còn lại là các dân tộc khác [3;2]. Những năm qua, dưới sự chỉ đạo của các cấp ủy đảng và chính quyền các cấp, tình hình kinh tế - xã hội vùng dân tộc và miền núi của tỉnh đã có nhiều chuyển biến tích cực. Nhiều chính sách dân tộc đã được triển khai và thực hiện có hiệu quả góp phần làm thay đổi đáng kể diện mạo nông thôn miền núi và vùng đồng bào dân tộc thiểu số trên địa bàn tỉnh. Đời sống vật chất và tinh thần của đồng bào dân tộc thiểu số ngày một nâng lên, tỷ lệ hộ nghèo giảm bình quân từ 3-5\%/ năm $[3 ; 2]$.

Tuy nhiên, hiện nay "kinh tế - xã hội ở một số địa phương có đông đồng bào dân tộc thiểu số trong tỉnh chưa phát triển", “đời sống một bộ phận nhân dân vùng sâu, vùng xa còn khó khăn”, "kết cấu hạ tầng 
nông thôn ở các xã, thôn, bản vùng sâu, vùng xa còn hạn chế", "chất lượng giáo dục, y tế, văn hóa ở vùng dân tộc thiểu số so với mặt bằng chung của tỉnh vẫn còn thấp" [3;19]. Thực tiễn đó cho thấy, việc đánh giá những kết quả đã đạt được trong thực hiện chính sách dân tộc, từ đó đưa ra những giải pháp nhằm nâng cao hiệu quả thực hiện chính sách dân tộc đang là nhiệm vụ cấp bách nhằm phát triển kinh tế - xã hội bền vững, đảm bảo ổn định an ninh chính trị ở tỉnh Tuyên Quang hiện nay.

\section{Nội dung nghiên cứu}

\subsection{Một số khái niệm}

\section{Chính sách dân tộc}

Hiện nay, khái niệm "chính sách dân tộc" được luận giải phong phú và có nhiều cách tiếp cận khác nhau. Tuy nhiên, hiểu một cách chung nhất, "chính sách dân tộc chính là tổng hợp những quan điểm, đường lối, chính sách của Đảng và Nhà nước được đề ra, tác động trực tiếp đến các dân tộc và quan hệ dân tộc" [2;178], qua đó góp phần nâng cao chất lượng mọi mặt cho các dân tộc và vùng đồng bào dân tộc ở Việt Nam.

\section{Thục hiện chính sách dân tộc}

"Thực hiện chính sách dân tộc là việc đưa pháp luật, chính sách vào cuộc sống trên cơ sở cụ thể hóa các Nghị quyết của Đảng, Nhà nước từ khâu hướng dẫn, thông tin, phân công trách nhiệm, chuẩn bị các điều kiện nguồn lực tài chính, nhân lực cần thiết bảo đảm thực hiện đúng mục tiêu, tiến độ theo yêu cầu quy định trong chính sách" [2;178].

Chính sách dân tộc là một trong những chính sách lớn của Nhà nước ta. Đây cũng là một công cụ quản lý nhà nước quan trọng, tác động trực tiếp đến mọi mặt đời sống kinh tế, chính trị, xã hội vùng đồng bào dân tộc thiểu số. Thực hiện tốt chính sách này góp phần duy trì sự ổn định và phát triển vùng đồng bào dân tộc thiểu số ở Việt Nam. Hiện nay, trong bối cảnh đất nước ta đang trong quá trình đẩy mạnh công nghiệp hóa, hiện đại hóa đất nước và tiến hành quá trình hội nhập quốc tế ngày càng sâu rộng thì việc thực hiện chính sách dân tộc càng có ý nghĩa quan trọng khi nó thực sự đi vào cuộc sống nhằm tạo ra bước chuyển biến mới trong phát triển kinh tế - xã hội vùng đồng bào dân tộc thiểu số.

2.2 Nhũng kết quả đạt được trong việc thực hiện một số chính sách đối với vùng đồng bào dân tộc thiểu số tỉnh Tuyên Quang

Nội dung bài viết này tập trung đánh giá kết quả thực hiện chính sách dân tộc ở tỉnh Tuyên Quang trong thời gian từ năm 2018 đến hết năm 2019. Việc thực hiện chính sách dân tộc ở tỉnh Tuyên Quang được chia theo hai nhóm chính sách: nhóm các chính sách chung và nhóm các chính sách đặc thù cho vùng đồng bào dân tộc thiểu số.

\section{a, Nhóm các chính sách chung}

Với đặc điểm có 22 dân tộc cùng chung sống, bên cạnh một số dân tộc sống tập trung thành làng, bản nhất định, thì phần lớn các dân tộc sống xen kẽ lẫn nhau nên các chính sách chung của tỉnh đã tác động không nhỏ tới đời sống của đồng bào các dân tộc.

Về thực hiện các chính sách phát triển kinh tế

Để đẩy mạnh phát triển kinh tế - xã hội, Tuyên Quang tập trung thu hút phát triển mạnh công nghiệp, tập trung vào một số ngành có lợi thế như: chế biến gỗ; sản xuất - chế biến nông - lâm sản, vật liệu xây dựng; khai thác, chế biến khoáng sản, may mặc, công nghiệp da giầy, cơ khí phục vụ nông nghiệp, nông thôn. Nhờ đó, giá trị sản xuất công nghiệp liên tục tăng. Nếu như năm 2018, giá trị sản xuất công nghiệp đạt 14.305 tỷ đồng [3;11] thì đến năm 2019 đạt 15.660 tỷ đồng, tăng 9,5\% so với năm 2018; sản lượng một số sản phẩm tăng khá so với năm 2018 [7;1]. Sản xuất nông - lâm nghiệp có nhiều chuyển biến tích cực, nhất là việc chuyển đổi cơ cấu cây trồng, vật nuôi theo hướng sản xuất hàng hóa tập trung; việc ứng dụng các tiến bộ khoa học kỹ thuật vào quá trình sản xuất, chế biến, bảo quản, tiêu thụ sản phẩm được chú trọng mang lại hiệu quả kinh tế cao. Sản lượng lương thực hàng năm đều đạt và vượt kế hoạch đề ra. Giá trị sản xuất nông - lâm nghiệp, thủy sản năm 2019 đạt 8.407,5 tỷ đồng, tăng 4,4\% so với năm 2018 (năm 2018 đạt 8.054,7 tỷ đồng) [7;1], [3;11].

Hoạt động du lịch có nhiều chuyển biến tích cực. Tỉnh đã tập trung xây dựng các chương trình, kế hoạch, quy hoạch, đề án phát triển du lịch để tổ chức hiệu quả. Việc đầu tư xây dựng các làng văn hóa gắn với phát triển du lịch được quan tâm thực hiện. Hiện nay, các làng văn hóa - du lịch được triển khai ở nhiều huyện trong tỉnh, trong đó tập trung chủ yếu ở huyện Chiêm Hóa (thôn Bó Củng, xã Kim Bình) và huyện Lâm Bình (Thôn Nà Tông, Tông Nà Đông, xã Thượng Lâm; thôn Nà Muông, xã Khuôn Hà; thôn Nặm Đíp, xã Lăng Can...). Số lượng khách du lịch đến Tuyên Quang liên tục tăng, năm 2018 tỉnh thu hút 1.712 nghìn lượt khách du lịch $[3 ; 12]$ thì đến năm 2019 tăng lên 1.945,7 nghìn lượt [7; 2], tăng 233,7 lượt. 
Việc xây dựng kết cấu hạ tầng, nhất là ở các xã, thôn bản đặc biệt khó khăn được quan tâm đầu tư. Mạng lưới giao thông nông thôn liên hoàn được xây dựng đã đáp ứng nhu cầu vận chuyển hàng hóa, giao lưu đi lại, thúc đẩy phát triển kinh tế - xã hội. Đến nay, $100 \%$ số xã trên địa bàn tỉnh có đường ô tô đến trung tâm, trong đó $95,04 \%$ số xã, thị trấn có đường nhựa hóa hoặc bê tông hóa. Tỷ lệ thôn, bản có đường ô tô đến trung tâm thôn đạt 99,81\% [3;12]. Các công trình xây dựng đường điện và trạm biến áp cung cấp điện cho các xã miền núi, xã có đông đồng bào dân tộc thiểu số được ưu tiên đầu tư xây dựng. Toàn tỉnh có $100 \%$ số xã và $98,82 \%$ hộ dân được sử dụng điện lưới quốc gia $[3 ; 12]$. Chương trình mục tiêu quốc gia Xây dựng nông thôn mới đạt được những kết quả đáng ghi nhận. Nhiều tấm gương điển hình là người dân tộc thiểu số đã tham gia hiến đất, đóng góp công sức, tiền của để làm đường giao thông nông thôn, kênh mương thủy lợi, nhà sinh hoạt cộng đồng... Năm 2019, toàn tỉnh có 07 xã đạt chuẩn nông thôn mới, nâng tồng số xã đạt chuẩn nông thôn mới lên 37 xã, bình quân toàn tỉnh đạt trên 14 tiêu chí / xã [7;2].

Về thục hiện chính sách củng cố, xây dựng hệ thống chính trị

Tuyên Quang tiếp tục thực hiện có hiệu quả các Nghị quyết Trung ương 4 (khóa XI, XII) về xây dựng Đảng. Công tác xây dựng Đảng và hệ thống chính trị ở các xã đặc biệt khó khăn được chú trọng, trong đó công tác phát triển đảng viên vùng sâu, vùng xa, vùng đồng bào dân tộc ít người được thực hiện nghiêm túc theo tinh thần Nghị quyết số $56-\mathrm{NQ} / \mathrm{TU}$ ngày 17/06/2009 của Ban Thường vụ Tỉnh ủy về đẩy mạnh công tác phát triển đảng viên vùng sâu, vùng xa, vùng đồng bào dân tộc thiểu số. Kết quả, đến năm 2019, 100\% thôn, bản đã có chi bộ độc lập, không còn thôn, bản chưa có đảng viên $[3 ; 16]$. Đội ngũ cán bộ các cấp, nhất là cấp chiến lược đủ phẩm chất, năng lực và uy tín ngang tầm nhiệm vụ được xây dựng theo tinh thần Nghị quyết Trung ương 7 (khóa XII). Tăng cường công tác đào tạo, bồi dưỡng nâng cao chất lượng cán bộ, công chức ở cấp cơ sở, quan tâm bố trí cán bộ là người dân tộc thiểu số tham gia hệ thống chính trị các cấp; đổi mới, nâng cao hiệu quả hoạt động của Hội đồng nhân dân các cấp. Trình độ cán bộ ở cấp cơ sở ngày càng được nâng cao. Năm 2019, toàn tỉnh có trên 2.900 cán bộ, công chức cấp xã, trong đó có trên 1.400 cán bộ, công chức là người dân tộc thiểu số; cán bộ có trình độ chuyên môn từ trung cấp trở lên chiếm 97\%, trong đó, số cán bộ có trình độ cao đẳng, đại học chiếm $58 \%$ [3;17].

\section{Về thực hiện các chính sách phát triển xã hội}

Công tác giảm nghèo toàn tỉnh nói chung và giảm nghèo trong đồng bào dân tộc thiểu số nói riêng đã được các cấp, các ngành triển khai có hiệu quả. Nhiều phong trào thi đua giảm nghèo diễn ra sôi nổi, tình hình đời sống nhân dân được nắm bắt thường xuyên; hộ nghèo, cận nghèo, gia đình có hoàn cảnh khó khăn được hỗ trợ kịp thời. Tỷ lệ hộ nghèo hàng năm đều giảm và vượt kế hoạch đề ra. Tỷ lệ hộ nghèo giảm từ $15,38 \%$ năm $2018[6 ; 2]$ xuống còn $11,8 \%$ năm 2019 [7;4]. Giáo dục, đào tạo được đổi mới căn bản, toàn diện, góp phần nâng cao chất lượng nguồn nhân lực của tỉnh. Năm 2019, 100\% các xã có trường mầm non, trường tiểu học, trung học cơ sở; các cụm xã có trường trung học phổ thông, tạo điều kiện cho con em đồng bào dân tộc thiểu số được theo học tại tất cả các cấp học, các bậc học. Việc giải quyết việc làm cho người lao động được chú trọng. Năm 2019, tỉnh hỗ trợ tạo việc làm cho khoảng 25.000 lao động, tăng 2.605 người so với năm 2018 [7;4]. Công tác phòng, chống tệ nạn xã hội, phòng chống ma túy, nhất là ở vùng đồng bào dân tộc thiểu số được chú trọng.

Về thưc hiện các chính sách xây dụng và phát triển văn hóa, con người đáp ứng yêu cầu phát triển bền vĩng

Tỉnh quan tâm tổ chức thực hiện Nghị quyết Trung ương 9 (khóa XI) về xây dựng, phát triển văn hóa con người Việt Nam đáp ứng yêu cầu phát triển bền vững đất nước. Các phong trào xây dựng đời sống văn hóa, gia đình văn hóa, thôn, bản, tổ dân phố, cơ quan, đơn vị, doanh nghiệp văn hóa được đẩy mạnh. Tỉnh cũng triển khai thực hiện hiệu quả các chính sách bảo tồn và phát huy các giá trị văn hóa vật thể và phi vật thể của các dân tộc trên địa bàn tỉnh đồng thời vinh danh những đóng góp tích cực trong lĩnh vực văn học - nghệ thuật, di sản văn hóa phi vật thể. Nhằm nâng cao chất lượng chăm sóc sức khỏe cho nhân dân, tỉnh thực hiện tốt công tác phòng chống dịch bệnh, nâng cao chất lượng khám chữa bệnh cho nhân dân. Đến năm 2019, trên địa bàn tỉnh có $82,2 \%$ trạm y tế xã có bác sỹ; bình quân toàn tỉnh có 8,1 bác sỹ/10.000 dân. Toàn tỉnh có 62 thầy thuốc ưu tú và 01 thầy thuốc nhân dân, trong đó có 08 thầy thuốc ưu tú là người dân tộc thiểu số $[3 ; 14]$.

Về thực hiện chính sách củng cố, xây dụng quốc phòng - an ninh

Công tác đảm bảo quốc phòng - an ninh trên địa bàn tỉnh được triển khai hiệu quả. Lực lượng vũ trang địa phương tiếp tục được xây dựng, củng cố về tổ 
chức, quân số; lực lượng dân quân tự vệ đạt 1,7\% so với dân số [3;17]. Công tác giao quân hàng năm được tổ chức tốt, đảm bảo $100 \%$ chỉ tiêu được giao. Tỉnh đã lựa chọn 2.618 thanh niên là người dân tộc thiểu số thực hiện nghĩa vụ quân sự và 589 đồng chí ở cơ sở để tạo nguồn cán bộ $[3 ; 18]$. Phong trào bảo vệ an ninh Tổ quốc được duy trì thường xuyên với sự tham gia, phối hợp chặt chẽ của đồng bào các dân tộc thiểu số. Chú trọng thực hiện công tác noi gương, chọn người có uy tín trong đồng bào dân tộc thiểu số tham gia phối hợp trong việc tuyên truyền chủ trương đường lối của Đảng, chính sách và pháp luật của Nhà nước, giữ gìn an ninh trật tự và xây dựng khối đại đoàn kết toàn dân tộc.

\section{b, Nhóm chính sách đặc thù}

Về thực hiện các chính sách phát triển kinh tế- xã hội, giảm nghèo vùng đồng bào dân tộc thiểu số

Nhằm phát triển kinh tế - xã hội, cải thiện đời sống cho đồng bào dân tộc thiểu số, tỉnh Tuyên Quang đã triển khai thực hiện hiệu quả nhiều chính sách dân tộc như: chính sách hỗ trợ trực tiếp cho người dân thuộc hộ nghèo ở vùng khó khăn theo Quyết định số 102/2009/QĐ-Ttg ngày 07/07/2009 của Thủ tướng Chính phủ; chính sách hỗ trợ đất ở, đất sản xuất, nước sinh hoạt cho hộ đồng bào dân tộc thiểu số nghèo và hộ nghèo ở xã, thôn, bản đặc biệt khó khăn theo Quyết định số $7555 / \mathrm{Q} Đ-T t g$ ngày 20/5/2013 của Thủ tướng Chính phủ; Quyết định số 2085/QĐ-TTg ngày 31/10/2016 của Thủ tướng Chính phủ về phê duyệt chính sách đặc thù hỗ trợ phát triển kinh tế - xã hội vùng dân tộc thiểu số và miền núi giai đoạn 2017-2020...

Để thực hiện giảm nghèo bền vững cho vùng đồng bào dân tộc thiểu số, từ nguồn vốn Chương trình 135 và Chương trình $30 \mathrm{a}$, Tuyên Quang đã hỗ trợ xây dựng, duy tu cơ sở hạ tầng cho các xã, thôn, bản đặc biệt khó khăn, hỗ trợ đồng bào phát triển sản xuất. Kết quả từ năm 2018 đến năm 2019, tỉnh đã hỗ trợ xây dựng mới 374 công trình (trong đó năm 2018: 197 công trình, năm 2019: 177 công trình) [ 4; 5], [5;5]. Các công trình được hỗ trợ xây mới chủ yếu là đường giao thông, nhà văn hóa, các công trình thủy lợi, nhà lớp học, sân thể thao, chợ, các công trình điện sinh hoạt và nước sinh hoạt. Các dự án hỗ trợ phát triển sản xuất, đa dạng hóa sinh kế và nhân rộng các mô hình giảm nghèo được thực hiện với 5.584 triệu đồng [3; 4]. Từ dự án, các hộ nghèo và cận nghèo được hỗ trợ giống, cây trồng vật nuôi, máy móc, thiết bị sản xuất và thức ăn chăn nuôi. Căn cứ
Quyết định số: 2086/QĐ-Ttg ngày 31/10/2016 của Thủ tướng Chính phủ về phê duyệt Đề án hỗ trợ phát triển kinh tế - xã hội các dân tộc thiểu số rất ít người giai đoạn 2016-2025, trong 2 năm 2018-2019 từ nguồn vốn ngân sách Trung ương, tỉnh đã phân bổ 5.043 triệu đồng để thực hiện. Đã có trên 350 lượt hộ được hỗ trợ; xây dựng 07 mô hình tổ hợp tác [3; 6].

Về thưc hiện các chính sách về bảo tồn và phát triển văn hóa, thông tin tuyên truyền vùng đồng bào dân tộc thiểu số

Công tác bảo tồn, phát huy các giá trị văn hóa truyền thống của đồng bào dân tộc thiểu số được chú trọng. Tuyên Quang đã hoàn thành kiểm kê di sản văn hóa phi vật thể của 16 dân tộc trên địa bàn tỉnh, trình Bộ Văn hóa, Thể thao và Du lịch đưa vào danh mục di sản văn hóa phi vật thể Quốc gia 09 hồ sơ di sản phi vật thể, đã có 07 hồ sơ được công nhận [3; 10]. Thực hành "Then Tày, Nùng, Thái" được UNESCO công nhận là di sản văn hóa phi vật thể đại diện của nhân loại [7; 4]. Các lễ hội truyền thống của đồng bào dân tộc thiểu số được phục dựng đồng thời duy trì các Câu lạc bộ văn hóa dân gian của đồng bào dân tộc như: Câu lạc bộ hát Then - đàn Tính của dân tộc Tày; Câu lạc bộ hát Páo Dung của dân tộc Dao... Nhiều chương trình phát thanh, truyền hình tiếng dân tộc thiểu số đã ra đời góp phần tuyên truyền sâu rộng trong đồng bào dân tộc thiểu số các chủ trương của Đảng, chính sách và pháp luật của Nhà nước. Hàng năm, tỉnh tổ chức phát một số ấn phẩm báo, tạp chí cho vùng dân tộc thiểu số và miền núi, vùng đặc biệt khó khăn theo Quyết định số 2472/QĐ-Ttg ngày 28/12/2011, Quyết định số 633/QĐ-Ttg ngày 19/4/2016 và Quyết định số 59/QĐ-Ttg ngày 16/01/2017 của Thủ tướng Chính phủ. Theo đó, trong 02 năm 2018 và 2019 , tỉnh đã cấp 18 loại báo, tạp chí với số lượng 852.227 tờ [4;5], [5;8]. Nhờ được cấp miễn phí các loại báo, tạp chí, đồng bào dân tộc thiểu số trên địa bàn tỉnh được cập nhật các thông tin thời sự trong tỉnh, trong nước và quốc tế, nắm bắt được các chủ trương, đường lối của Đảng và chính sách, pháp luật của Nhà nước, từ đó chủ động thực hiện các chính sách và cảnh giác trước các âm mưu thủ đoạn của kẻ thù nhằm lợi dụng phá hoại khối đại đoàn kết dân tộc.

Về thưc hiện các chính sách về giáo dục, y tế, chăm sóc sức khỏe cho đồng bào dân tộc thiểu số

Những năm qua tỉnh đã quan tâm thực hiện việc đổi mới công tác dạy và học ở các cấp học, bậc học, giữ vững kết quả phổ cập giáo dục tiểu học đúng độ 
tuổi, hoàn thành phổ cập giáo dục cho trẻ mầm non 5 tuổi. Các chế độ đối với học sinh các trường dân tộc nội trú, trường bán trú theo Thông tư liên tịch số 109/2009/TTLT/BTC-BGDĐT ngày 29/5/2009 liên

Bộ Tài chính - Giáo dục và Đào tạo được thực hiện đầy đủ. Học sinh và trường phổ thông ở xã, thôn, bản đặc biệt khó khăn được hỗ trợ theo Nghị định 116/2016/NĐ-CP ngày 18/7/2016 của Chính phủ; trẻ mẫu giáo, học sinh, sinh viên dân tộc thiểu số ít người được hưởng chính sách ưu tiên theo Nghị định số 57/2017/NĐ-CP ngày 09/05/2017 của Chính. Đến năm 2019, trên địa bàn tỉnh đã có 399 học sinh dân tộc rất ít người được hỗ trợ với tổng kinh phí là 3.524 triệu đồng [3; 9]. Từ nguồn ngân sách tỉnh và hỗ trợ từ dự án Hỗ trợ y tế các tỉnh vùng Đông Bắc Bộ và Đồng Bằng sông Hồng, Tuyên Quang đã thực hiện hỗ trợ $100 \%$ mức đóng bảo hiểm y tế cho người thuộc hộ cận nghèo, đảm bảo 100\% người thuộc hộ nghèo, cận nghèo, người dân tộc thiểu số sống ở vùng khó khăn, người dân sống ở vùng đặc biệt khó khăn được cấp thẻ bảo hiểm y tế [3; 9]. Hệ thống cơ sở vật chất y tế và chất lượng đội ngũ cán bộ y tế vùng đồng bào dân tộc thiểu số ngày càng được nâng cao, góp phần chăm sóc sức khỏe cho đồng bào dân tộc thiểu số.

Về thực hiện chinh sách đối với người có uy tín trong vùng đồng bào dân tộc thiểu số

Hàng năm, Ban Dân tộc tỉnh chủ trì, phối hợp với Ban Thường trực Ủy ban Mặt trận Tổ quốc tình, Công an tỉnh triển khai, rà soát, bầu chọn bổ sung danh sách người có uy tín trong vùng đồng bào dân tộc thiểu số trên địa bàn tỉnh theo Quyết định số 12/2018/QĐ-Ttg ngày 06/3/2018 của Thủ tướng Chính phủ. Năm 2019, toàn tỉnh có 1.247 người có uy tín trong đồng bào dân tộc thiểu số $[5 ; 6]$. Người có uy tín được cấp phát đầy đủ các loại báo theo quy định, được thăm hỏi, động viên kịp thời theo đúng chính sách đã quy định về ốm đau, qua đời, gia đình không may gặp rủi ro, thiên tai. Tỉnh đã tổ chức nhiều hội nghị tập huấn, bồi dưỡng kiến thức, cung cấp thông tin cho người có uy tín trên địa bàn tỉnh. Đại biểu người có uy tín trên địa bàn tỉnh được bầu chọn đã phát huy vai trò tích cực trong công tác phổ biến, tuyên truyền các chủ trương của Đảng, chính sách và pháp luật của Nhà nước ở nơi cư trú; kịp thời trao đổi thông tin, phản ánh tâm tư nguyện vọng chính đáng của quần chúng nhân dân đối với cấp ủy, chính quyền các cấp, giữ vững khối đại đoàn kết dân tộc; góp phần tích cực trong công tác giảm nghèo, xây dựng nông thôn mới.
Về thực hiện các chính sách phổ biến, giáo dục pháp luật và tuyên truyền vận động đồng bào vùng dân tộc thiểu số

Thực hiện đề án "Đẩy mạnh công tác phổ biến, giáo dục pháp luật và tuyên truyền vận động đồng bào dân tộc thiểu số và miền núi giai đoạn 2017 2021" theo Quyết định số 1163/QĐ-TTg ngày 08/8/2017 của Thủ tướng Chính phủ, trong 2 năm 2018 và 2019 , Ban dân tộc tỉnh đã phối hợp với Ủy ban nhân dân các huyện tổ chức nhiều hội nghị phổ biến, giáo dục pháp luật cho hàng trăm đại biểu, trong đó có các đại biểu là cán bộ làm công tác dân tộc cấp huyện, cấp xã; trưởng thôn, bản; đại diện các tổ chức đoàn thể thôn, bản và đồng bào dân tộc thiểu số ở các xã đặc biệt khó khăn. Các nội dung tuyên truyền tập trung vào các quy định pháp luật về hôn nhân và gia đình, an toàn giao thông, phòng chống tội phạm buôn bán người, phòng chống bạo lực gia đình, các chủ trương, chính sách dân tộc của Đảng và Nhà nước...

Đề án giảm thiểu tình trạng tảo hôn và hôn nhân cận huyết thống trong vùng đồng bào dân tộc thiểu số theo Quyết định số 498/QĐ-Ttg ngày 14/4/2015 của Thủ tướng Chính phủ được triển khai theo hướng chọn mô hình điểm để thực hiện. Năm 2018, Ban Dân tộc tỉnh đã tổ chức điều tra, khảo sát, thu thập thông tin, đánh giá thực trạng tình trạng tảo hôn ở các xã đặc biệt khó khăn thuộc 6 huyện trên địa bàn tỉnh, sau đó chọn 02 xã (xã Hùng Lợi và xã Trung Minh huyện Yên Sơn) làm mô hình điểm để thực hiện Đề án. Theo đó, tỉnh đã tổ chức 07 hội nghị tuyên truyền "Giảm thiểu tình trạng tảo hôn và hôn nhân cận huyết trong vùng đồng bào dân tộc thiểu số" trên địa bàn tỉnh với 731 đại biểu tham gia $[4 ; 6]$. Năm 2019, từ đánh giá kết quả thực hiện 02 mô hình điểm ở huyện Yên Sơn, Ban dân tộc tỉnh tiếp tục xây dựng kế hoạch để nhân rộng mô hình thực hiện Đề án trên địa bàn xã Xuân Lập, huyện Lâm Bình; trực tiếp hướng dẫn thành lập mô hình và tập huấn kỹ năng tuyên truyền cho Ban chỉ đạo cấp xã và thành viên Tổ tư vấn thôn, bản của xã Xuân Lập.

Đề án "Hỗ trợ hoạt động bình đẳng giới vùng dân tộc thiểu số giai đoạn 2018 - 2025 theo Quyết định số 1898/QĐ-Ttg ngày 28/11/2017 của Thủ tướng Chính phủ được triển khai thực hiện nghiêm túc. Ban Dân tộc tỉnh đã phối hợp với Ủy ban nhân dân huyện Chiêm Hóa chỉ đạo duy trì, hướng dẫn hoạt động của Câu lạc bộ "Tăng cường sự tham gia của phụ nữ và thúc đẩy bình đẳng giới” ở xã Linh Phú, tổ chức đoàn đại biểu gồm 10 người đại diện thành viên Câu lạc bộ 
tham dự Hội nghị tập huấn nâng cao kiến thức pháp luật do Ủy ban dân tộc tổ chức tại Hà Nội, đồng thời chỉ đạo tổ chức đánh giá sơ kết 01 năm thực hiện mô hình tại xã Linh Phú.

Nhờ tích cực thực hiện các chính sách dân dân tộc, hai năm qua, vùng đồng bào dân tộc thiểu số tỉnh Tuyên Quang đã có sự phát triển, công tác giảm nghèo đạt được nhiều kết quả quan trọng. Đời sống vật chất, tinh thần của đồng bào từng bước được nâng lên. Với tinh thần đoàn kết, phát huy nội lực, vượt qua những khó khăn, đồng bào dân tộc thiểu số trên địa bàn tỉnh đã tích cực thực hiện các phong trào thi đua yêu nước, các cuộc vận động do các cấp, các ngành phát động, cùng với cấp ủy, chính quyền địa phương triển khai thực hiện có hiệu quả chương trình, chính sách của Nhà nước, củng cố khối đại đoàn kết dân tộc, từ đó góp phần quan trọng vào những kết quả, thành tựu mà tỉnh đã đạt được trong thời gian qua.

\subsection{Một số hạn chế trong thực hiện chính sách dân tộc ở tỉnh Tuyên Quang}

Qua nghiên cứu thực trạng thực hiện chính sách dân tộc ở tỉnh Tuyên Quang từ năm 2018 đến năm 2019 cho thấy đã đạt được những kết quả đáng khích lệ. Tuy nhiên, bên cạnh những kết quả đạt được, trong việc thực hiện chính sách dân tộc cũng còn tồn tại một số hạn chế. Trong phát triển kinh tế nông lâm nghiệp vùng đồng bào dân tộc thiểu số, năng suất, chất lượng sản phẩm một số cây trồng vật nuôi còn thấp. Chất lượng giảm nghèo chưa thật sự bền vững, tỷ lệ hộ nghèo là người dân tộc thiểu số còn cao. Đời sống một bộ phận đồng bào dân tộc thiểu số còn gặp nhiều khó khăn, nhiều hộ đồng bào dân tộc thiểu số chưa biết cách làm ăn, chủ yếu làm ăn manh mún, nhỏ lẻ, dựa vào khai thác rừng, làm nông, khai thác những nguồn lực tự nhiên sẵn có để sinh sống; sức lao động cũng chủ yếu dựa vào sức người, hạn chế trong việc áp dụng các tiến bộ khoa học kỹ thuật vào trong sản xuất. Thời gian gần đây, tuy đã bắt đầu áp dụng những công nghệ tiên tiến, máy móc vào trong sản xuất nhưng vẫn còn ít và thiếu đồng bộ. Một bộ phận đồng bào dân tộc thiểu số chưa chủ động trong thực hiện các chính sách, còn ỷ lại vào các chính sách hỗ trợ của nhà nước. Kinh tế một số địa phương có đông đồng bào dân tộc thiểu số chưa phát triển, việc chuyển dịch cơ cấu kinh tế nông nghiệp theo hướng sản xuất hàng hóa gắn với thị trường chuyển biến chậm.

Kết cấu hạ tầng nông thôn của tỉnh tuy được tăng cường đầu tư nhưng chưa thực sự đáp ứng nhu cầu phát triển kinh tế - xã hội. Ở một số thôn, bản vùng sâu, vùng xa chưa có đường bê tông vào thôn, nên nhân dân đi lại rất khó khăn như thôn Trung Phìn, thôn Khuổi Phìn, xã Sinh Long; thôn bản Bung, xã Thanh Tương, Na Hang... Đặc biệt tại thôn Trung Phìn và thôn Khuổi Pìn (Sinh Long, $\mathrm{Na}$ Hang) và một số thôn, bản khác ở các xã vùng sâu, vùng xa thuộc một số huyện miền núi hiện nay chưa có điện lưới quốc gia vào thôn bản nên đời sống nhân dân rất khó khăn. Chất lượng giáo dục, văn hóa, y tế ở vùng dân tộc thiểu số so với mặt bằng chung của tỉnh còn thấp. Ở một số địa phương, trong vùng dân tộc thiểu số còn xảy ra tình trạng tảo hôn, đưa người đi lao động nước ngoài trái phép. Việc triển khai thực hiện một số chương trình, chính sách dân tộc còn có những khó khăn, bất cập. Ví dụ, việc bố trí vốn để thực hiện các chính sách đặc thù hỗ trợ vùng dân tộc thiểu số theo Quyết định số 2085/QĐ-Ttg ngày 31/10/2016 và Quyết định số 2086/QĐ-Ttg ngày 31/10/2016 của Thủ tướng Chính phủ còn hạn chế, chưa đảm bảo theo kế hoạch đã đề ra [5;11].

Nguyên nhân của những hạn chế trên là do kinh tế của tỉnh vẫn còn khó khăn, nguồn thu ngân sách hạn chế, vì vậy việc bố trí nguồn lực cho công tác giảm nghèo chưa đáp ứng được nhu cầu. Một số địa phương chưa chủ động phát huy được tiềm năng, thế mạnh để phục vụ cho công tác phát triển kinh tế - xã hội. Xuất phát điểm kinh tế - xã hội vùng đồng bào dân tộc thiểu số thấp. Địa hình vùng dân tộc thiểu số phức tạp, giao thông đi lại không thuận tiện, ảnh hưởng đến việc tiếp nhận các dịch vụ, khoa học, kỹ thuật và công nghệ của đồng bào dân tộc thiểu số. Sự phối hợp giữa các ngành, các cấp có lúc chưa chặt chẽ.

2.4. Một số giải pháp nhằm nâng hiệu quả chính sách dân tộc ở tỉnh Tuyên Quang

Để khắc phục những hạn chế nêu trên và thực hiện có hiệu quả các chính sách dân tộc ở tỉnh Tuyên Quang cần sự vào cuộc quyết liệt của cả hệ thống chính trị, các cấp, các ngành và đồng thời phải thực hiện đồng bộ nhiều giải pháp, trong đó cần thực hiện những giải pháp cơ bản sau:

Một là, tăng cường vai trò lãnh đạo của các cấp ủy Đảng, chính quyền tỉnh Tuyên Quang trong triển khai thực hiện chính sách dân tộc. Trong đó, tập trung giải quyết kịp thời, có hiệu quả những mong muốn chính đáng của đồng bào dân tộc thiểu số trong triển khai thực hiện các chính sách.

Hai là, nâng cao nhận thức của cán bộ, đảng viên và nhân dân về tầm quan trọng của chính sách dân tộc và thực hiện chính sách dân tộc thông qua việc tuyên truyền, giáo dục về các chủ trương, chính sách dân tộc, giáo dục nâng cao tinh thần cảnh giác cách mạng cho đồng bào dân tộc thiểu số. 
Ba là, tổ chức triển khai thực hiện có hiệu quả từng chính sách trên cơ sở bám sát tình hình thực tiễn địa phương để vận dụng các chính sách có hiệu quả.

Bốn là, tăng cường công tác kiểm tra, giám sát, đánh giá quá trình thực hiện chính sách dân tộc, đặc biệt hướng tới khuyến khích người dân, các tổ chức quần chúng cùng tham gia kiểm tra, giám sát việc thực hiện các chính sách.

Năm là, tăng cường quản lý nhà nước về công tác dân tộc thông qua việc hoàn thiện pháp luật về công tác dân tộc, xây dựng hệ thống chính sách rõ ràng, cụ thể, không chồng chéo, mâu thuẫn, thống nhất đầu mối cơ quan chủ trì, tổ chức thực hiện chính sách đáp ứng yêu cầu, nhiệm vụ công tác dân tộc.

\section{Kết luận}

Tuyên Quang là một tỉnh có sự đa dạng về thành phần dân tộc. Các dân tộc trên địa bàn tỉnh giàu truyền thống đoàn kết, yêu nước, cùng gắn bó với nhau trong quá trình sinh sống. Mặc dù đồng dân tộc thiểu số nơi đây cư trú đan xen nhưng đều có bản sắc văn hóa riêng. Trong tiến trình đổi mới đất nước, đảng bộ, chính quyền và nhân dân các dân tộc ở tỉnh Tuyên Quang đã tích cực chủ động tổ chức thực hiện chính sách dân tộc của Đảng và Nhà nước trên địa bàn và đã thu được nhiều thành tựu quan trọng nhưng cũng không tránh khỏi một số hạn chế nhất định. Giải quyết đúng đắn và sáng tạo những khó khăn, hạn chế trong quá trình thực hiện sẽ góp phần phát triển kinh tế - xã hội, thay đổi diện mạo của vùng đồng bào dân tộc thiểu số ở Tuyên Quang trên tinh thần đoàn kết, thống nhất, không ngừng khắc phục khó khăn về mọi mặt để phát triển, khẳng định ý chí vươn lên, tính tự lực tự cường, tin tưởng sâu sắc vào sự lãnh đạo của Đảng trong công cuộc đổi mới hiện nay. Qua đó, chúng ta càng tin tưởng khẳng định rằng, đồng bào dân tộc thiểu số ở Tuyên Quang sẽ phát triển xa hơn, tiến kịp với các dân tộc khác, cùng góp sức xây dựng và bảo vệ quê hương, đất nước giàu mạnh.

\section{REFERENCES}

1- Vietnam Communist Party, Document of the XI National Congress of Delegates, National Political Publishing House, Hanoi, 2011

2- Ho Chi Minh National Academy of Politics, High-level curriculum of political theory: Ethnic theory and ethnic relations in Vietnam, Political Theory Publishing House, Hanoi, 2019, p. 13.14

3-People's Committee of Tuyen Quang province, Documents of the third Congress of ethnic minorities in Tuyen Quang province in 2019

4-People's Committee of Tuyen Quang province, Committee for Ethnic Minorities, Report on summary of ethnic affairs in 2018, directions and tasks of ethnic affairs in 2019

5-People's Committee of Tuyen Quang province, Committee for Ethnic Minorities, Report on the implementation of ethnic work in 2019, directions and tasks of ethnic work in 2020

6-People's Committee of Tuyen Quang province, Report on results of implementation of socioeconomic development tasks in 2018; expected socio-economic development plan in 2019

7-People's Committee of Tuyen Quang province, Report on results of implementation of socioeconomic development tasks in 2019, expected socio-economic development plan 2020

\section{THE RESULTS OF IMPLEMENTING ETHNIC POLICY IN TUYEN QUANG PROVINCE}

\section{Article info}

Recieved:

28/4/2020

Accepted:

20/9/2020

Keywords:

ethnicity, ethnic policy, Tuyen Quang province, ethnic minorities, ethnic minority areas.

\begin{abstract}
Ethnic policy is one of the important contents, aiming at socio-economic development in ethnic minority areas across the our country. This article focuses on evaluating the achievements and limitations in the process of implementing ethnic policy in Tuyen Quang province, as well as coming up with solutions to improve efficiency of ethnic policy implementation in the locality.
\end{abstract}

